\title{
The Engagement Level of Board Members and Associated Health Care Quality in Public Health Centers of Addis Ababa, Ethiopia, 2018
}

\author{
Assalif Beyene Haile (D) \\ Mesfin Beyene Haile ${ }^{2}$ \\ Abebe Mihretie Dagnaw' \\ Eyosiyas Yeshialem Asefa $\mathbb{D}^{\prime}$ \\ Michael Amera Tizazu (D) \\ 'Midwifery Department, Health Science \\ College, University of Debre Berhan, \\ Debre Berhan, Ethiopia; ${ }^{2}$ Addis Ababa \\ Health Bureau, Addis Ababa, Ethiopia
}

Background: A board member was an important bridge to accelerate a day-to-day health care quality in a routine clinical activity at health institutions. They are significant in planning and examine integrated governance systems that encourage quality of care and accountability. So, the current research was planned to identify the level of engagement of the board members in health care quality and factors associated.

Methods: A facility-based cross-sectional study was implemented among 250 board members and data were collected by self-administered questionnaire at selected governing health centers in Addis Ababa, Ethiopia from May 1 to 30, 2018. A simple random sampling technique was used to reach the study participants. Data were entered using EpiData 3.1 software and analysis was done using SPSS 23. Adjusted odds ratio with $95 \%$ confidence interval and p-value $<0.05$ was used to declare statistical significance. The level of board members' engagement was found to be low which implies that the board members do not give appropriate attention to the quality of care.

Results: Good level of engagement of board members was $(50.9 \%)$ [AOR $=7.11,95 \% \mathrm{CI}$ (3.07-16.47)]. Most of the governing board members did not engage in the quality of health care activities. Uses quality data as a basis for recognition [AOR=7.11, 95\% CI (3.07-16.47)], review a quality scorecard or dashboard [AOR $=10.83,95 \%$ CI (3.75-31.29)], establishing goals relating to staff satisfaction $[\mathrm{AOR}=15.42,95 \%$ CI (6.14-38.75)] and receiving formal training $[\mathrm{AOR}=3.42,95 \% \mathrm{CI}(1.35-8.62)]$, having a strategy relating to communication with clients $[\mathrm{AOR}=4.95,95 \% \mathrm{CI}(2.02-12.15)]$ and spending more than $20 \%[\mathrm{AOR}=11.96,95 \% \mathrm{CI}(3.27-43.83)]$, received training on healthcare disparities $[\mathrm{AOR}=3.81,95 \% \mathrm{CI}(1.40-10.36)]$, and having a plan on quality [AOR $=16.3895 \% \mathrm{CI}$ (5.39-49.72)] were found to be significant predictors of level of board member engagement. Conclusion: Collectively, most of the governing board members did not engage in the quality of health care activities. Stakeholders should work on capacity building for board members using training and further follow-up. Encouraging them to put quality health services at the forefront of their agenda during their involvement at their respective facilities. Keywords: clinical governance, health center, health care quality, Ethiopia

\section{Introduction}

A clinical governing body makes decisions about clinical setting plans and rules of collective action. For health organizations, the focus of this collective action is to strengthen health systems to expand access to quality health care services. ${ }^{1}$ This leads to better, more sustainable health outcomes. Clinical governance/Board
Correspondence: Assalif Beyene Haile University of Debre Berhan, P. O. Box: 445, Debre Berhan, Ethiopia Tel +25I 91।712023/+251946690434 Email assalif2522@gmail.com 
members of the health organizations were seen as a key vehicle for developing a shared commitment high-quality care in the everyday performance of the health institutions. The health facility governing boards have a responsibility in making the quality of health care services remains a key concern for policymakers and practitioners all over the world and developing appropriate organizational strategies, courages and values to implement the delivery of quality within their organization. ${ }^{2}$ Following weakness in leadership quality, failure to recognize a problem, lack of assurance and challenge, inadequate risk management and implementation of policies, procedures, protocols, and guidelines among board members results for poor delivery of quality health care services in health care organizations. ${ }^{3}$ Globally, there is a growing literature which shows that the health care facility board members' activities matter for better, safer patient care. ${ }^{4}$ The decision-making power is shifted from the central or upper location to a lower level has been pushed as a real means to attract the quality and achieve the desired result without wastage of health systems in developing countries. However, the real situation proposes that such activities have been unsuccessful due to a shortage of transparent governance roles and relationships. ${ }^{5}$ Reports in the U.S. showed that various health care organizations were unable to provide key evidence-based treatments. One area of particular recent interest is leadership and governance by boards of directors that oversee the health facility. ${ }^{5}$ The problems also did not decline in Asia and Africa. In South Africa, the board members tend to forget their responsibility on the health care system because most of them are a politician and fail to perform what the community needs in the health care quality systems. ${ }^{6}$

In Ethiopia, the study showed that the lack of commitment of board members to meet regularly and to attend meetings with motivations was insufficient. In some cases, board members' were over devoted to more than one board and members were too busy to arrange their governing board tasks. ${ }^{7}$ Socio-demographic factors such as (sex, educational status, profession) and quality-related activities have been identified as risk factors for the engagement of board members for quality health care. Similarly, administration-related and organizational resources were also found to be associated with board members' engagement on health care quality. ${ }^{7,8}$

The Ethiopian government takes policy-based commitment to relieve the problems associated with the engagement of board members in quality health care service. Therefore, this study planned to determine the engagement of board members and their associated factors. Results from this study will add to the current knowledge about board members' engagement and identify its factors of engagement of board members for quality health care service. The findings of this study will serve for other studies as well as for planning health care interventions to improve the quality of patient care in the health institutions.

\section{Methods}

\section{Study Setting and Design}

An Institutional-based quantitative cross-sectional study design has been conducted from May 1 to 30/2018.

\section{Study Settings}

This study had been conducted in the capital and largest city of Ethiopia, Addis Ababa. The city for the Ethiopian federal government seat. The city has 45 hospitals, 92 governmental health centers, and 551 clinics. In this study alone, public health centers were assessed which had a total of 644 governing boards. Each health center is supported by board members assigned by the Ministry of Health. All board members in each health center were required to have a quality health care service committee.

\section{Population}

\section{Source Population}

The primary source population of the study was all governing board members from all public health centers found in Addis Ababa.

\section{Study Population}

All health centers governing board members from randomly selected public health centers of Addis Ababa were included.

\section{Eligibility}

\section{Inclusion Criteria}

All selected governing bodies of health centers that provided services for more than six months during the data collection period were included in the study.

\section{Exclusion Criteria}

Governing bodies of health centers on annual leave, seriously sick, and unable to respond during the data collection period were excluded. 


\section{Sample Size Determination}

The sample size was determined by using a single population proportion formula by considering

$$
\mathrm{n}=\frac{Z_{a / 2}^{2} p(1-p)}{d^{2}} \text { Where, }
$$

$\mathrm{Z} \alpha / 2=$ critical value $=1.96(\mathrm{Z}$ value at $95 \% \mathrm{CL})$, $\mathrm{P}$ (estimated proportion) $=0.64$ from study done in Adwa town, ${ }^{8}$ and $\mathrm{d}$ (Margin of error) $=0.05$. The final sample size was calculated considering $10 \%$ of non-response rate became 250 .

\section{Sample Technique}

Among all governmental public health centers found in the Addis Ababa city administration Health bureau ( 92 health centers), 37 health centers were included by using a simple random sampling technique. The sample size assigned to the study was distributed proportionally to each selected health center. All 250 governing board members from the selected health institutions were recruited to the study randomly.

\section{Study Variables \\ Dependent Variable}

Board member engagement.

\section{Independent Variables}

Socio-demographic (sex, educational status, profession), Quality-related activities, organizational variables, Quality-related activities, organizational resources, and administration-related variables.

\section{Data Collection and Procedures}

The data were collected using self-administered questionnaires. The questionnaire was conducted by two trained data collectors and supervisors. The questionnaire was prepared in English language and translated to Amharic language and back to English to check for language consistency. The questionnaire was adopted from the United States by Epstein and Jha and other peer-reviewed articles. ${ }^{4}$ A questionnaire consists of socio-demographic characteristics, Quality-related activities, organizational resources, and administration-related variables.

\section{Measurement}

Engagement of board members in quality of health care was measured using 12 quality-related activities (Board had established quality plan, performance related with quality was presented on every board meeting agenda, at least quarterly board members monitored care plan of the quality, and incidental quarterly review of data, Board member uses data as a base for the provision of recognition, Board review quality dashboard at least quarterly, develops future goals related to staff satisfaction, measures whether staff attending or received formal training that addresses the quality of care, the strategy was developed to communicate with patients by board members, the quality of health care against external benchmarks was monitored by board members, more than $20 \%$ of board members spent their time for quality issues, and formally board members received training on health care disparities).

Good engagement $=$ board members which fulfilled $\geq$ six activities among the list of 12 quality-related activities had been considered as good engagement in the quality of care.

Poor engagement $=$ board members which fulfilled less than six (50\%) among the list of 12 quality-related activities had been considered as poor engagement in the quality of care.

\section{Data Quality Control}

To ensure data quality, training was given to data collectors and supervisors. The questionnaire, originally developed in English, was translated to Amharic and back to English to check its consistency. The selfadministered questionnaire was given in the English language. Before collecting the actual data a $5 \%$ of the total study sample was pre-tested for feasibility and generation of reliable and valid information. Vigilant examination of completed questionnaires was checked and the quality of the recordings was done through daily supervision by field supervisors.

\section{Data Processing and Analysis}

Data were entered, cleared, and coded into EpiData software version 3.1 and then exported to SPSS version 23, where further statistical analyses were done. To quantify the level of engagement on the board members and other characteristics, descriptive statistics were done. As recommended by scholars, bivariate logistic regression analysis was done for each of the independent variables. The independent variables with a $p$-value of $\leq 0.25$ in the bivariate analysis were purposely selected for Variables with a $\mathrm{P}$ value of less than 0.25 on bivariate logistic regression were selected for the multivariate logistic 
regression analyses. After all, significant associations between the level of board member engagement and each independent variable entered the multivariate logistic regression analyses were declared at $\mathrm{P}$-values of $<$ 0.05. The corresponding 95\% Confidence Interval (CI) with Adjusted Odds Ratio (AOR) was used to explain the strength of associations between the dependent and explanatory variables. A 0.05 level of significance was used to declare the significance of statistical tests and the results were presented in texts and tables.

\section{Ethical Consideration}

From the Addis Ababa Regional Health Bureau (AARHB), Ethical committee of health Science College of Menelik II, University of Addis Ababa ethical clearance letter was secured. Written informed consent was obtained from study participants. Study subjects had the right to self-determination towards participation in the study, at the beginning and during the study. For confidentiality, the participant names were not incorporated in the questionnaire. The collected data used only for the study were kept confidential and the Declaration of Helsinki was maintained to conduct this study.

\section{Results}

\section{Socio-Demographic Characteristics of Respondents}

A total of 250 board members were expected to participate in the study, while 232 respondents in our study had a response rate of $92.8 \%$. More than half $123(53.0 \%)$ of the respondents were between the age group of 30-39 years with a mean age of 38.08 years. The majority of the board members 158 (68.1\%) were male while 79 (34.1\%) of surveyed board members were health professionals. Additionally, 81 (34.9\%) of board members had work experience of 3-4 years (Table 1).

\section{Level of Engagement and Quality-Related} Activities

More than three fourth (78.4\%) of the board members had a plan on the quality of their respective health centers, while only $43.1 \%$ of board members presented a Quality performance on the agenda at each board member's meeting. Additionally, more than half 157 (67.7\%) of respondents were received formal training for quality of care and only $41(17.7 \%)$ of board members assessed the organization's performance against external benchmarks. Generally, this

Table I Socio-Demographic Characteristics of Respondents Board Members in Addis Ababa ( $\mathrm{N}=232)$

\begin{tabular}{|c|c|c|c|}
\hline \multicolumn{2}{|l|}{ Variables } & \multirow{2}{*}{$\begin{array}{r}\text { Count } \\
27\end{array}$} & \multirow{2}{*}{$\begin{array}{r}\text { Percentage } \% \\
11.6 \%\end{array}$} \\
\hline Age categorized & 20-29 years & & \\
\hline & $30-39$ years & 123 & $53.0 \%$ \\
\hline & $40-49$ years & 62 & $26.7 \%$ \\
\hline & Greater or equal to 50 & 20 & $8.6 \%$ \\
\hline \multirow[t]{2}{*}{ Sex of participant } & Male & 158 & $68.1 \%$ \\
\hline & Female & 74 & $31.9 \%$ \\
\hline \multirow{5}{*}{$\begin{array}{l}\text { Participant educational } \\
\text { level }\end{array}$} & Less than 12 & 46 & $19.8 \%$ \\
\hline & 12 completed & 18 & $7.8 \%$ \\
\hline & Certificate & 3 & $1.3 \%$ \\
\hline & Diploma & 11 & $4.7 \%$ \\
\hline & Degree and above & 154 & $66.4 \%$ \\
\hline \multirow[t]{4}{*}{ Board experience } & Less than 3 years & 46 & $19.8 \%$ \\
\hline & $3-4$ years & 81 & $34.9 \%$ \\
\hline & $5-6$ years & 67 & $28.9 \%$ \\
\hline & 6 and above years & 38 & $16.4 \%$ \\
\hline \multirow[t]{5}{*}{ Board member profession } & Health professional & 79 & $34.1 \%$ \\
\hline & Social science & 44 & $19.0 \%$ \\
\hline & Teachers & 34 & $14.7 \%$ \\
\hline & Natural science & 73 & $31.5 \%$ \\
\hline & Others & 2 & $0.9 \%$ \\
\hline
\end{tabular}


study revealed that the level of good board member engagement on quality health care in our study area is $118(50.9 \%)$ (Table 2).

\section{Administrative and Organizational Resources}

The majority of Board members 142 (61.2\%) did not allocate time to work with quality issues indicated that there was no system for prioritizing quality services at the Board member levels and more than half (56.5\%) of members were the right expertise for working with quality improvement. Of the total respondents, very few 41 (17.7\%) board members had compensation attached to quality goals. The majority 173 (74.6\%) of board members had no documents that guide what to do on quality issues and about $141(60.8 \%)$ respondents did not get administrative support from governments relating to quality health services. Concerning standardized quality measures, 190 $(81.9 \%)$ of respondents indicated that there were no standards at the Board level and only 48 (20.7\%) of respondents had quality subcommittees that monitor quality services (Table 3).

\section{Factors Affecting the Engagement of Board Members on the Quality of Health Care Services}

We selected: use of quality data as a basis for recognition, reviewed a quality scorecard or dashboard at least

Table 2 Quality-Related Activities Undertaken by Board Members of Public Health Centers and Level of Board Member Engagement in Addis Ababa Ethiopia $(n=232)$

\begin{tabular}{|c|c|c|c|}
\hline \multicolumn{2}{|l|}{ Quality-Related Activities Undertaken by Board Members } & \multirow{3}{*}{$\begin{array}{l}\text { Count } \\
50 \\
182\end{array}$} & \multirow{3}{*}{$\begin{array}{l}\text { Percentage \% } \\
21.6 \% \\
78.4 \%\end{array}$} \\
\hline Does the board have a plan on quality & No & & \\
\hline & Yes & & \\
\hline \multirow[t]{2}{*}{ Does Quality performance is presented on the agenda at every board meeting? } & No & 132 & $56.9 \%$ \\
\hline & Yes & 100 & $43.1 \%$ \\
\hline \multirow[t]{2}{*}{ Does the Board monitored progress toward quality of care plan at least quarterly? } & No & 160 & $69.0 \%$ \\
\hline & Yes & 72 & $31.0 \%$ \\
\hline \multirow[t]{2}{*}{ Does Board reviews data on incidents at least quarterly? } & No & 177 & $76.3 \%$ \\
\hline & Yes & 55 & $23.7 \%$ \\
\hline \multirow[t]{2}{*}{ Does Board uses quality data as basis for recognition } & No & 92 & $39.7 \%$ \\
\hline & Yes & 140 & $60.3 \%$ \\
\hline \multirow[t]{2}{*}{ Does Board review a quality scorecard or dashboard at least quarterly? } & No & 179 & $77.2 \%$ \\
\hline & Yes & 53 & $22.8 \%$ \\
\hline \multirow[t]{2}{*}{ Does Board has established goals relating to staff satisfaction? } & No & 147 & $63.4 \%$ \\
\hline & Yes & 85 & $36.6 \%$ \\
\hline \multirow[t]{2}{*}{ As a Board member received formal training that covers quality of care? } & No & 75 & $32.3 \%$ \\
\hline & Yes & 157 & $67.7 \%$ \\
\hline \multirow[t]{2}{*}{ Does Board has a strategy relating to communication with patients? } & No & 83 & $35.8 \%$ \\
\hline & Yes & 149 & $64.2 \%$ \\
\hline \multirow[t]{2}{*}{ Does Board monitored quality of care against external benchmarks? } & No & 191 & $82.3 \%$ \\
\hline & Yes & 41 & $17.7 \%$ \\
\hline \multirow[t]{2}{*}{ Does Board spends more than $20 \%$ of its time on quality of health care issues? } & No & 189 & $81.5 \%$ \\
\hline & Yes & 43 & $18.5 \%$ \\
\hline \multirow[t]{2}{*}{ Does Board member received training on healthcare disparities? } & No & 177 & $76.3 \%$ \\
\hline & Yes & 55 & $23.7 \%$ \\
\hline \multirow[t]{2}{*}{ Level of board member engagement } & Poor engagement & 114 & $49.1 \%$ \\
\hline & Good engagement & 118 & $50.9 \%$ \\
\hline
\end{tabular}


Table 3 Administrative and Organizational Characteristics of Boards of Health Centers in Addis Ababa Ethiopia ( $n=232)$

\begin{tabular}{|c|c|c|c|}
\hline \multicolumn{2}{|l|}{ Administrative and Board Organizational Characteristics } & \multirow{3}{*}{$\begin{array}{l}\text { Count } \\
142 \\
90\end{array}$} & \multirow{3}{*}{$\begin{array}{l}\text { Percentage \% } \\
61.2 \% \\
38.8 \%\end{array}$} \\
\hline Does the board member have time to work with quality issue? & No & & \\
\hline & Yes & & \\
\hline \multirow[t]{2}{*}{ As the Board member do you have the right competence for Working with quality improvement } & No & 101 & $43.5 \%$ \\
\hline & Yes & $|3|$ & $56.5 \%$ \\
\hline \multirow{2}{*}{ Does the board member have compensation attached to quality goals? } & No & 191 & $82.3 \%$ \\
\hline & Yes & 41 & $17.7 \%$ \\
\hline \multirow[t]{2}{*}{ Are there documents on which Board members should do in quality improvement? } & No & 173 & $74.6 \%$ \\
\hline & Yes & 59 & $25.4 \%$ \\
\hline \multirow[t]{2}{*}{ As the Board member have you got administrative support for working with quality } & No & $|4|$ & $60.8 \%$ \\
\hline & Yes & 91 & $39.2 \%$ \\
\hline \multirow[t]{2}{*}{ Does the board member have standardized quality measures? } & No & 190 & $81.9 \%$ \\
\hline & Yes & 42 & $18.1 \%$ \\
\hline \multirow[t]{2}{*}{ Does the board establish a quality subcommittee } & No & 184 & $79.3 \%$ \\
\hline & Yes & 48 & $20.7 \%$ \\
\hline \multirow[t]{2}{*}{ As a board member are you familiar with some Organisational risk factors? } & No & 134 & $57.8 \%$ \\
\hline & Yes & 98 & $42.2 \%$ \\
\hline \multirow[t]{2}{*}{ In your opinion skills in quality of care issues was important when recommending new board appointees } & No & 98 & $42.2 \%$ \\
\hline & Yes & 134 & $57.8 \%$ \\
\hline \multirow[t]{2}{*}{ In your opinion quality of care issue was a core part of board members } & No & 65 & $28.1 \%$ \\
\hline & Yes & 166 & $71.9 \%$ \\
\hline \multirow[t]{2}{*}{ As board members are you easily identified quality performance indicators from reports } & No & 138 & $59.5 \%$ \\
\hline & Yes & 94 & $40.5 \%$ \\
\hline \multirow[t]{2}{*}{ Does board members used reports for strategic decision making process? } & No & 80 & $34.5 \%$ \\
\hline & Yes & 152 & $65.5 \%$ \\
\hline \multirow[t]{2}{*}{ Does the board member receive the right report timely } & No & 27 & $11.6 \%$ \\
\hline & Yes & 205 & $88.4 \%$ \\
\hline
\end{tabular}

quarterly, established goals relating to staff satisfaction, received formal training that addresses quality of care, having strategy regarding communication with patients, spent more than $20 \%$ of their time on the quality of health care, received training on healthcare disparities, do you have time to work with the quality issue, having competence for working with quality improvement, identify quality performance indicators from reports, and use reports for strategic decision-making process as a candidate for multiple logistic regression analysis based on the criteria described on methodology part.

Accordingly, board members who use quality data as a basis for recognition had higher odds of good level engagement $[\mathrm{AOR}=7.11,95 \% \mathrm{CI}(3.07-16.47)]$ on quality of health care than those who did not use it.
Similarly, those who review a quality scorecard or dashboard at least quarterly are more than 10 times more likely to have good engagement on health center quality care $[\mathrm{AOR}=10.83$, 95\% CI (3.75-31.29)]. Establishing goals relating to staff satisfaction and receiving formal training that covers the quality of care was significantly associated with the level of engagement on quality care with $\quad[\mathrm{AOR}=15.42, \quad 95 \% \quad \mathrm{CI} \quad(6.14-38.75)] \quad$ and $\left[\mathrm{AOR}=3.42, \quad 95 \% \quad \mathrm{CI} \quad\left(\begin{array}{lll}1.35 & -8.62)\end{array}\right), \quad\right.$ respectively. Additionally, having a strategy relating to communication with clients and spending more than $20 \%$ of their time on the quality of health care increases the level of board members engagement on health centers quality of care by about $5[\mathrm{AOR}=4.95,95 \% \mathrm{CI}(2.02-12.15)]$ and 12 times $[\mathrm{AOR}=11.96,95 \% \mathrm{CI}(3.27-43.83)]$. 
Finally, board members who received training on healthcare disparities, and having a plan on quality had higher odds of engaging in quality of care in health centers with $[\mathrm{AOR}=3.81,95 \% \mathrm{CI}(1.40-10.36)]$, and $[\mathrm{AOR}=16.38$ 95\% CI (5.39-49.72)] than their counterparts, respectively.

On contrary, having time to work with the quality issue [AOR $=1.57,95 \%$ CI (0.69-3.59)], having competence for working with quality improvement $[\mathrm{AOR}=2.1095 \% \mathrm{CI}$ (0.96-4.62)], identifying quality performance indicators from reports $[\mathrm{AOR}=1.33,95 \% \mathrm{CI}(0.57-3.10)]$, and using reports for strategic decision-making process [AOR $=1.75$ 95\% CI (0.76-4.03)] were found to be not significantly associated with the level of good engagement of board members on the quality of health care services (Table 4).

\section{Discussion}

This study identified that the level of good engagement of board members on the quality of health care services in our study area be 118 (50.9\%). This finding is consistent with the study done in Australia and the UK where there are low levels of board members engagement in the process of overseeing quality priorities. ${ }^{7,9}$ This was too low as expected to be $100 \%$ since the association between health leadership and quality, is crucial to driving quality improvement. This was supported by a study done regarding the hospital board and management practices related to hospital performance. ${ }^{5}$ The level of performance of board members in this study area was lower than an interventional study done in Adwa town, Tigray region which showed a higher performance level of board members even before intervention (64\%) and after the intervention to $(85 \%){ }^{10}$

Table 4 Factors Affecting Engagement of Board Members on Quality of Health Care Services in Public Health Centers of Addis Ababa, Ethiopia $(n=232)$

\begin{tabular}{|c|c|c|c|c|c|}
\hline & & \multicolumn{2}{|c|}{ Board Member Engagement } & \multirow[t]{3}{*}{ COR $(95 \% \mathrm{Cl})$} & \multirow[t]{3}{*}{ AOR $(95 \% \mathrm{Cl})$} \\
\hline & & \multirow{2}{*}{$\begin{array}{c}\text { Poor Engagement } \\
\text { Count (\%) }\end{array}$} & \multirow{2}{*}{$\frac{\text { Good Engagement }}{\text { Count (\%) }}$} & & \\
\hline & & & & & \\
\hline \multirow[t]{2}{*}{ Uses quality data as basis for recognition } & No & $63(55.3 \%)$ & 29 (24.6\%) & 1 & 1 \\
\hline & Yes & $5 \mathrm{I}(44.7 \%)$ & 89 (75.4\%) & $3.79(2.17-6.63)$ & $7.11(3.07-16.47)^{*}$ \\
\hline \multirow[t]{2}{*}{ Review a quality scorecard or dashboard at least quarterly? } & No & $102(89.5 \%)$ & 77 (65.3\%) & I & I \\
\hline & Yes & $12(10.5 \%)$ & $41(34.7 \%)$ & $4.53(2.23-9.19)$ & $10.83(3.75-31.29)^{*}$ \\
\hline \multirow[t]{2}{*}{ Established goals relating to staff satisfaction? } & No & 94 (82.5\%) & $53(44.9 \%)$ & & 1 \\
\hline & Yes & $20(17.5 \%)$ & $65(55.1 \%)$ & $5.76(3.15-10.54)$ & $15.42(6.14-38.75)^{*}$ \\
\hline \multirow[t]{2}{*}{ Received formal training that covers quality of care? } & No & 46 (40.4\%) & $29(24.6 \%)$ & I & I \\
\hline & Yes & $68(59.6 \%)$ & 89 (75.4\%) & $2.08(1.18-3.64)$ & $3.42(1.35-8.62)^{*}$ \\
\hline \multirow[t]{2}{*}{ Has a strategy relating to communication with clients? } & No & $51(44.7 \%)$ & 32 (27.l\%) & 1 & 1 \\
\hline & Yes & $63(55.3 \%)$ & $86(72.9 \%)$ & $2.18(1.26-3.77)$ & $4.95(2.02-12.15)^{*}$ \\
\hline \multirow{2}{*}{ Spends more than $20 \%$ of its time on quality of health care } & No & 100 (87.7\%) & 89 (75.4\%) & 1 & 1 \\
\hline & Yes & 14 (12.3\%) & $29(24.6 \%)$ & $2.33(1.16-4.68)$ & $11.96(3.27-43.83)^{*}$ \\
\hline \multirow[t]{2}{*}{ Received training on healthcare disparities? } & No & $96(84.2 \%)$ & 81 (68.6\%) & 1 & 1 \\
\hline & Yes & $18(15.8 \%)$ & 37 (3I.4\%) & $2.44(1.29-4.60)$ & $3.81(1.40-10.36)^{*}$ \\
\hline \multirow[t]{2}{*}{ Does you have time to work with quality issue? } & No & 75 (65.8\%) & 67 (56.8\%) & 1 & 1 \\
\hline & Yes & $39(34.2 \%)$ & $51(43.2 \%)$ & $1.46(0.86-2.49)$ & $1.57(0.69-3.59)$ \\
\hline \multirow[t]{2}{*}{ Competence for Working with quality improvement } & No & $62(54.4 \%)$ & 39 (33.1\%) & I & I \\
\hline & Yes & $52(45.6 \%)$ & 79 (66.9\%) & $2.41(1.42-4.11)$ & $2.10(0.96-4.62)$ \\
\hline \multirow[t]{2}{*}{ Identify quality performance indicators from reports } & No & 77 (67.5\%) & 61 (5I.7\%) & 1 & 1 \\
\hline & Yes & $37(32.5 \%)$ & $57(48.3 \%)$ & $1.94(1.14-3.31)$ & $1.33(0.57-3.10)$ \\
\hline \multirow[t]{2}{*}{ Use reports for strategic decision making process? } & No & 49 (43.0\%) & $31(26.3 \%)$ & 1 & I \\
\hline & Yes & 65 (57.0\%) & 87 (73.7\%) & $1.59(0.70-3.59)$ & $1.75(0.76-4.03)$ \\
\hline \multirow[t]{2}{*}{ Does the board have a plan on quality } & No & 35 (30.7\%) & $15(12.7 \%)$ & I & 1 \\
\hline & Yes & 79 (69.3\%) & $103(87.3 \%)$ & $3.04(1.55-5.96)$ & $16.38(5.39-49.72)^{*}$ \\
\hline
\end{tabular}

Note: NB*Significant.

Abbreviations: AOR, adjusted odds ratio; COR, crude odds ratio. 
From the independent variables included in multivariable logistic regression, Board members who had a plan on quality of health care, using quality data as a basis for recognition, spending more than $20 \%$ of their time on the quality of health care, and reviewing a quality scorecard or dashboard at least quarterly were significantly associated with the level of board members engagement on the quality of health care. This might be because recognizing staff based on the quality of care by revising their performances using a quality scorecard improves their relationship with staff members which may lead to better engagement. Additionally, spending more time working at facilities being assigned to make board members more familiar with the facility and improves their attachment with the health centers. This was supported by a study done in English hospitals where English board chairs had more expertise in quality-of-care issues and spent a greater proportion of their time on the quality of care. ${ }^{9}$ Similar studies implied that governing board members appear to be actively engaged in quality oversight, particularly through the use of internal data and national benchmarks to monitor the quality of performance of their organizations. ${ }^{11-14}$ Additionally, choosing to operate diligently focusing on strategy and monitoring, a close grip on business and strong support for executives were all significant. ${ }^{15}$

In addition establishing goals relating to staff satisfaction, receiving training on healthcare disparities, and receiving formal training that covers the quality of care were significantly associated with the level of engagement in quality care. This was consistent with the study done in four regional states which showed that improving implementation of their roles and responsibilities, and continuing training on business management were recommended to improve the role of board members on quality health care services. ${ }^{16}$ Similarly, a study done in Australia showed that more tailored board training on quality issues; smarter use of reporting and accreditation requirements; and better access to data that was reliable were significant factors of board members' effectiveness. ${ }^{17}$ This might be because having pre-defined goals and capacity-building training helps with directing each activity of quality improvement with better efficiency.

Finally, having a strategy relating to communication with clients increases the level of board members' engagement in the health centers' quality of care. This creates a better chance for board members to be closer to customers of their respective health facilities. This also enables them to find out more information regarding their health centers from the consumer side to plan and intervene accordingly. The finding of this study was supported by the study implying that board and health care staffs to be engaged in management settings for discussion on quality and requiring the health facilities to report their quality/ safety performance to the general public. ${ }^{13}$

\section{Conclusions}

The level of board members' engagement in our study area was found to be low which needs further intervention from stakeholders to achieve their objective of the establishment.

This identified major determinant factors of the level of engagement to be considered by stakeholders during their intervention. So making the quality of care a forefront agenda of board members at their health facilities by providing formal training that covers the quality of care and on healthcare disparities, spending more than $20 \%$ of their time on quality improvement issues of health care, enabling them to focus on uses of quality data as the basis for recognition of health staff, and Reviewing a quality scorecard or dashboard at least quarterly.

\section{Acknowledgment}

We would like to thank almighty God for giving us the courage to do our research work. Secondly, we passed our acknowledgment to Menelik II Health Science College, Department of Public Health for giving us this chance to do this research. Our sincere and deepest gratefulness goes to our friends and colleagues for sharing valuable documents, their support in our performance, and sharing their experience. We would also like to thank data collectors, supervisors, board members, and staff working in health centers for their material and academic support.

\section{Disclosure}

The authors report no conflicts of interest in this work.

\section{References}

1. McNatt Z, Thompson JW, Mengistu A, et al. Implementation of hospital governing boards: views from the field. BMC Health Serv Res. 2014;14:1-9. doi:10.1186/1472-6963-14-178

2. Standard QIG. Australian commission on safety and quality in health care; 2012.

3. McDonagh KJ, Umbdenstock RJ. Hospital governing boards: a study of their effectiveness concerning organizational performance. $J$ Healthcare Manage. 2006;51:377. doi:10.1097/00115514200611000-00007

4. Jha A, Epstein A. Hospital governance and the quality of care. Health Aff. 2010;29:182-187. doi:10.1377/hlthaff.2009.0297 
5. Tsai TC, Jha AK, Gawande AA, Huckman RS, Bloom N, Sadun R. Hospital board and management practices are strongly related to hospital performance on clinical quality metrics. Health Aff. 2015;34:1304-1311. doi:10.1377/hlthaff.2014.1282

6. Brown A. Understanding corporate governance of healthcare quality: a comparative case study of eight Australian public hospitals. BMC Health Serv Res. 2019;19:1-14. doi:10.1186/s12913-019-4593-0

7. Pannick S, Sevdalis N, Athanasiou T. Beyond clinical engagement: a pragmatic model for quality improvement interventions, aligning clinical and managerial priorities. BMJ Qual Saf. 2016;25:716-725. doi:10.1136/bmjqs-2015-004453

8. Tadege TG. Assessment of board work performance and do an intervention in Adwa Hospital. Tigray, Ethiopia: Addis Ababa University; 2013.

9. Jha AK, Epstein AM. A survey of board chairs of English hospitals shows greater attention to the quality of care than among their US counterparts. Health Aff. 2013;32:677-685. doi:10.1377/ hlthaff.2012.1060

10. Gidey T. Assessment of board work performance and do an intervention in Adwa Hospital, Tigray, Ethiopia AAU Institutional Repository; 2913.

11. Lockee C, Fahe KB. Board engagement in quality: findings of a survey of hospital and system Leaders/PRACTITIONER APPLICATION. $J$ Healthcare Manage. 2008;53:121. doi:10.1097/00115514-20080 3000-00009
12. Vaughn T, Koepke M, Kroch E, Lehrman W, Sinha S, Levey S. Engagement of leadership in quality improvement initiatives: executive quality improvement survey results. J Patient Saf. 2006;2:2-9.

13. Jiang HJ, Lockee C, Fraser I. Enhancing board oversight on quality of hospital care: an agency theory perspective. Health Care Manage Rev. 2012;37:144-153. doi:10.1097/HMR.0b013e3182224237

14. Parand A, Dopson S, Renz A, Vincent C. The role of hospital managers in quality and patient safety: a systematic review. $B M J$ Open. 2014;4:e005055. doi:10.1136/bmjopen-2014-005055

15. Chambers N, Harvey G, Mannion R. Who should serve on health care boards? What should they do and how should they behave? A fresh look at the literature and the evidence. Cogent Business Manage. 2017;4:1357348. doi:10.1080/23311975.2017.1357348

16. Mesele Damte Argaw BFD. Examining Governing Board Functions and Health Center Performances During Health System Reform: a Cross-sectional Study in 4 Regional States of Ethiopia. international journal of health policy and management 2020 .

17. Bismark MM, Studdert DM. Governance of quality of care: a qualitative study of health service boards in Victoria, Australia. BMJ Qual Saf. 2014;23:474-482. doi:10.1136/bmjqs-2013-002193
Risk Management and Healthcare Policy

\section{Publish your work in this journal}

Risk Management and Healthcare Policy is an international, peerreviewed, open access journal focusing on all aspects of public health, policy, and preventative measures to promote good health and improve morbidity and mortality in the population. The journal welcomes submitted papers covering original research, basic science, clinical \& epidemiological studies, reviews and evaluations, guidelines, expert opinion and commentary, case reports and extended reports. The manuscript management system is completely online and includes a very quick and fair peer-review system, which is all easy to use. Visit http://www.dovepress.com/testimonials.php to read real quotes from published authors. 